\title{
Effect of carbon dioxide on the intraocular pressure in man during general anaesthesia
}

\author{
J. R. SAMUEL AND A. BEAUGIÉ \\ From the Research Department of Anaesthetics, Royal College of Surgeons, \\ and St. Peter's Hospital, London
}

The intraocular pressure (IOP) in man is known to vary during general anaesthesia (Kornblueth, Aladjemoff, Magora, and Gabbay, 1959), and the causes of such variations are numerous. Changes in the arterial carbon dioxide level have also been shown to produce observable changes in IOP, but most of these studies have been made in animals.

The present investigation was designed to examine the effects of different end-tidal concentrations of carbon dioxide on the human IOP during general anaesthesia. Accurate measurements of IOP were made with a Perkins hand-held tonometer (Perkins, 1965) in preference to a Schiötz tonometer which was used in most previous studies.

\section{Material and methods}

Ten otherwise healthy urological patients (9 male and I female, aged 24 to $75 \mathrm{yrs}$ ) were investigated. Apart from the tonometric measurements, there was no further interference with the patient other than was required for the surgical operation. They gave no history of eye disease or recent ophthalmic symptoms and none had been taking drugs known to alter IOP. The nature of the investigation was explained to each patient and his written consent was obtained. The respiratory and cardiovascular states were stabilized by modifying the method of Samuel, Grange, and Hawkins (1968), and substituting pancuronium for tubocurarine. Patients were not premedicated; anaesthesia was induced with thiopentone $(5 \mathrm{mg} . \mathrm{kg}$.), pancuronium $(\mathrm{O} \cdot \mathrm{I} \mathrm{mg} . / \mathrm{kg}$.$) , and pethidine$ ( $\mathrm{m} \mathrm{mg.} \mathrm{kg.).} \mathrm{The} \mathrm{vocal} \mathrm{cords} \mathrm{were} \mathrm{sprayed} \mathrm{with} \mathrm{lignocaine} \mathrm{(Io} \mathrm{mg} . / 7 \mathrm{~kg}$.) and a cuffed endotracheal tube was inserted. Ventilation was controlled with a Manley ventilator set at constant pressure with a constant gas flow of ${ }_{1} 5 \mathrm{l} / \mathrm{min}$. ( $\mathrm{N}_{2} \mathrm{O}$ io $1 . / \mathrm{min}$. and $\mathrm{O}_{2} 5 \mathrm{l} / \mathrm{min}$.), to minimize the effect of changes in intrathoracic pressure. The patients lay supine throughout the investigation.

The end-tidal carbon dioxide concentration $\left(\mathrm{FE}_{\mathrm{co} 2}^{\prime}\right)$ at the carina was measured by continuous sampling through a fine nylon catheter passed through the endotracheal tube mount. Samples were analysed by a Uras III infrared carbon dioxide analyser, the interference cells of which were filled with nitrous oxide to prevent overlap of the nitrous oxide and carbon dioxide absorption bands (Pierson, Fletcher, and Gantz, 1956). A fluorescein strip was applied to the conjunctiva and the IOP was measured with a Perkins hand-held applanation tonometer. In five patients a local anaesthetic (lignocaine 2 per cent.) was instilled into the conjunctival sac and the IOP measured before induction of anaesthesia. At the end of the investigation chloramphenicol ointment was applied and the eye was closed with adhesive tape.

The blood pressure (BP) was measured with a von Recklinghausen oscillotonometer; the central venous pressure (CVP) by a saline manometer connected to a catheter passed through an antecubital vein into the thorax; and the heart rate (HR) by palpation of a radial artery. 
The carbon dioxide level was maintained stable for at least io minutes before each measurement of IOP was made. Three levels of end-tidal $\mathrm{CO}_{2}$ percentage were chosen: 3,5 , and 8 per cent. The 3 per cent. level was achieved by hyperventilation alone and the two higher levels by the addition of $\mathrm{CO}_{2}$ to the inspired gases. The nitrous oxide flow was reduced by an equal mount to keep the concentration of inspired oxygen and the minute volume constant. At the end of each study the end-tidal $\mathrm{CO}_{2}$ concentration was brought back to the low level of 3 per cent. and the IOP was again measured. The IOP was measured three times by two observers at each concentration of $\mathrm{CO}_{2}$. The means of these values were calculated.

\section{Results}

The results of the whole group are shown in chronological order in Table I (overleaf). The figures in brackets are the percentage changes from the observations obtained when the carbon dioxide concentration was 5 per cent. In every case there was a marked rise in IOP when the concentration of carbon dioxide was increased. When the carbon dioxide concentration was returned again to the low level of 3 per cent. the IOP also fell near its former level. Thus, each patient acted as his own control. The typical changes in one patient are shown in Fig. I.

The means of the percentage changes in $\mathrm{IOP}$ and $\mathrm{CO}_{2}$ per cent. in the whole group (Fig. 2) emphasize their close relationship which is statistically highly significant $(\mathrm{P}<$

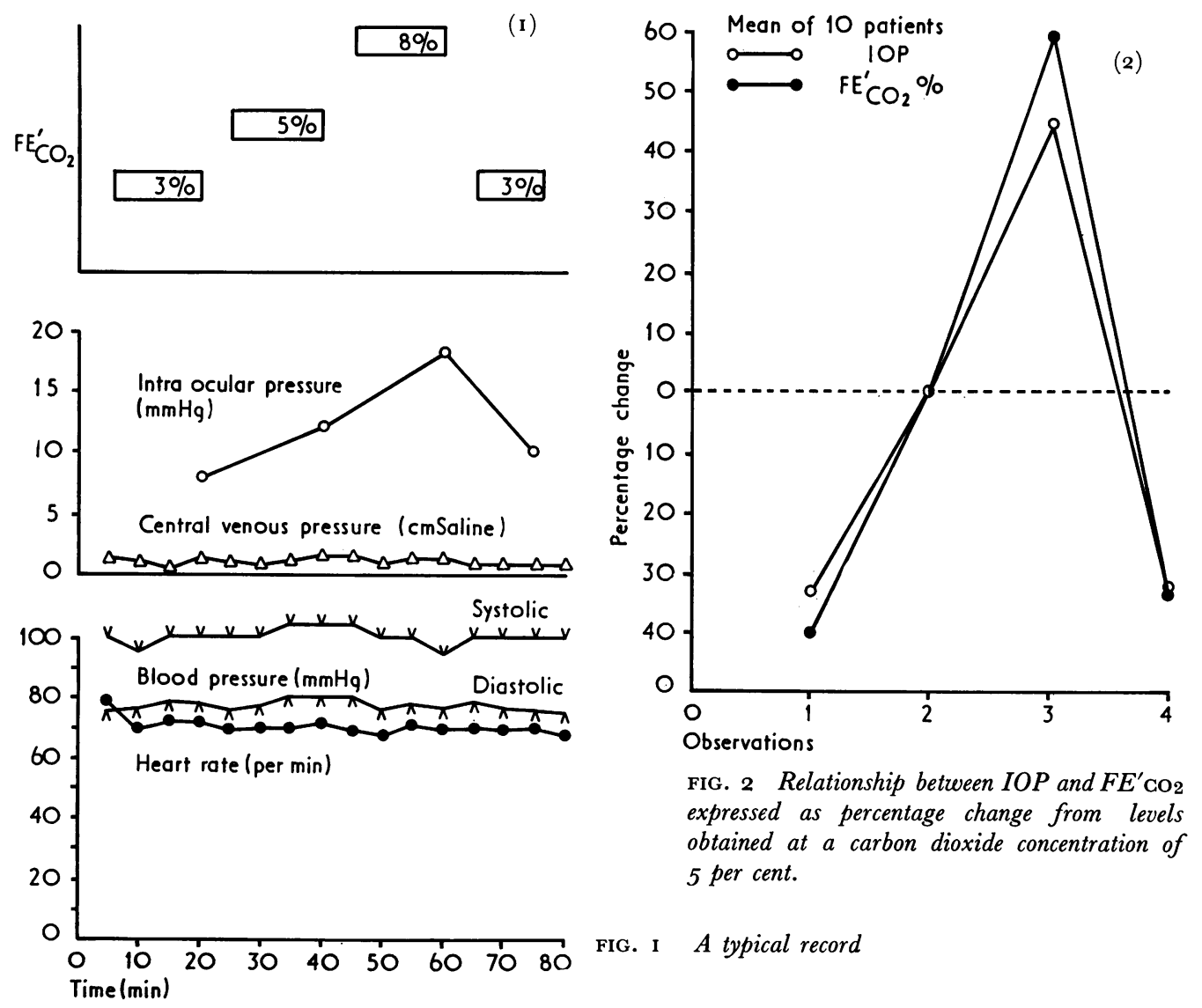


Table I

\begin{tabular}{|c|c|c|c|c|c|c|c|c|c|c|}
\hline \multirow{2}{*}{ Patient no. } & \multirow{2}{*}{$\begin{array}{l}\text { IOP } \\
\text { when } \\
\text { awake }\end{array}$} & \multicolumn{5}{|c|}{ Observation I } & \multicolumn{4}{|c|}{ Observation 2} \\
\hline & & $F E^{\prime} \mathrm{CO}_{2}$ & $I O P$ & $B P$ & $H R$ & $C V P$ & $F E^{\prime} \mathrm{CO}_{2}$ & $I O P$ & $B P$ & $H R$ \\
\hline I & & $\begin{array}{l}3 \cdot 0 \\
(-40 \cdot 0)\end{array}$ & $\begin{array}{l}6 \cdot 0 \\
(-47 \cdot 8)\end{array}$ & $\stackrel{90}{(-18 \cdot 2)}$ & $\begin{array}{l}76 \\
(5 \cdot 6)\end{array}$ & $\begin{array}{l}4 \cdot 5 \\
(0 \cdot 0)\end{array}$ & $5^{\circ} \mathrm{o}$ & I I 5 & I IO & 72 \\
\hline 2 & & $\begin{array}{l}3 \cdot 5 \\
(-30 \cdot 0)\end{array}$ & $\begin{array}{l}4 \cdot 0 \\
(-20 \cdot 0)\end{array}$ & $\begin{array}{l}120 \\
(0 \cdot 0)\end{array}$ & $\begin{array}{l}60 \\
(0 \cdot 0)\end{array}$ & $\begin{array}{l}-2 \\
(100 \cdot 0)\end{array}$ & $5 \cdot 0$ & $5 \cdot 0$ & I 20 & 55 \\
\hline 3 & & $\begin{array}{l}3 \cdot 0 \\
(-40 \cdot 0)\end{array}$ & $\begin{array}{l}6 \cdot 0 \\
(-50 \cdot 0)\end{array}$ & $\begin{array}{l}\text { I00 } \\
(-9 \cdot 1)\end{array}$ & $\begin{array}{l}\text { I00 } \\
(6 \cdot 7)\end{array}$ & 3 & $5 \cdot 0$ & $12 \cdot 0$ & IIO & IOO \\
\hline 4 & & $\begin{array}{l}3 \cdot 5 \\
(-36 \cdot 4)\end{array}$ & $\begin{array}{l}12 \cdot 0 \\
(-31 \cdot 4)\end{array}$ & $\begin{array}{l}100 \\
(-16 \cdot 7)\end{array}$ & $\begin{array}{l}80 \\
(-6 \cdot 3)\end{array}$ & $\begin{array}{l}\mathrm{I} \cdot 5 \\
(-25 \cdot 0)\end{array}$ & $5 \cdot 5$ & 17.5 & 120 & 75 \\
\hline 5 & 13 & $\stackrel{2 \cdot 5}{(-44 \cdot 4)}$ & $\begin{array}{l}\text { I I } 5 \\
(-42 \cdot 3)\end{array}$ & $\begin{array}{l}120 \\
(-14 \cdot 3)\end{array}$ & $\begin{array}{l}75 \\
(6 \cdot 3)\end{array}$ & $\begin{array}{l}4 \cdot 5 \\
(-10 \cdot 0)\end{array}$ & $4 \cdot 5$ & 13.0 & 140 & 80 \\
\hline 6 & 21 & $\begin{array}{l}3 \cdot 0 \\
(-40 \cdot 0)\end{array}$ & $\begin{array}{l}\mathbf{I I} \cdot 0 \\
(-3 \mathbf{I} \cdot 3)\end{array}$ & $\begin{array}{l}150 \\
(0 \cdot 0)\end{array}$ & ${ }^{85}(-4 \cdot 6)$ & $\begin{array}{l}6 \cdot 0 \\
(0 \cdot 0)\end{array}$ & 5.0 & $16 \cdot 0$ & 150 & 80 \\
\hline 7 & & $\begin{array}{l}3 \cdot 0 \\
(-40 \cdot 0)\end{array}$ & $\begin{array}{l}\mathbf{1} 4 \cdot 0 \\
(-26 \cdot 3)\end{array}$ & $\begin{array}{l}120 \\
(-7 \cdot 7)\end{array}$ & $\begin{array}{l}105 \\
(-6 \cdot 3)\end{array}$ & $\begin{array}{l}7 \\
(7 \cdot 7)\end{array}$ & $5^{\circ} 0$ & $19 \cdot 0$ & 130 & 110 \\
\hline 8 & $\overline{10}$ & $\begin{array}{l}3 \cdot 0 \\
(-40 \cdot 0)\end{array}$ & $\begin{array}{l}\mathrm{I} 3 \cdot 0 \\
(-3 \mathrm{I} \cdot 6)\end{array}$ & $\begin{array}{l}140 \\
(0 \cdot 0)\end{array}$ & $\begin{array}{l}75 \\
(6 \cdot 7)\end{array}$ & $\begin{array}{l}4 \\
(0 \cdot 0)\end{array}$ & $5 \cdot 0$ & $\overline{19.0}$ & $\overline{140}$ & $\overline{8 o}$ \\
\hline 9 & 14 & $\begin{array}{l}3 \cdot 0 \\
(-45 \cdot 5)\end{array}$ & $\begin{array}{l}8 \cdot 0 \\
(-33 \cdot 3)\end{array}$ & $\begin{array}{l}130 \\
(18 \cdot 2)\end{array}$ & $\begin{array}{l}80 \\
(0 \cdot 0)\end{array}$ & 3 & $5 \cdot 5$ & $\overline{12 \cdot 0}$ & $\overline{110}$ & 75 \\
\hline 10 & 24 & $\begin{array}{l}3 \cdot 0 \\
(-40 \cdot 0)\end{array}$ & $\begin{array}{l}12 \cdot 5 \\
(-16 \cdot 7)\end{array}$ & $\begin{array}{l}\text { I } 10 \\
(10 \cdot 0)\end{array}$ & $\begin{array}{l}85 \\
(0 \cdot 0)\end{array}$ & 5 & $5 \cdot 0$ & 15.0 & 100 & 85 \\
\hline $\begin{array}{l}\text { Mean per } \\
\text { cent. change }\end{array}$ & & - & $-33 \cdot 1$ & $-3 \cdot 8$ & -0.8 & 14.8 & & & & \\
\hline S.D. & & - & 10.4 & II $\cdot I$ & $5 \cdot 0$ & $34 \cdot 2$ & & & & \\
\hline $\mathrm{P}$ & & - & $>0.001$ & $\mathrm{NS}$ & $\mathrm{NS}$ & $\mathrm{NS}$ & & & & \\
\hline
\end{tabular}

Figures in brackets denote the percentage changes from the observations recorded at the 5 per cent. level of $\mathrm{CO}_{2}\left(\mathrm{Ob}_{8}\right.$ tion I)

$0 \cdot 00 \mathrm{I})$. The changes in heart rate and blood pressure were not significant and neither was the change in mean central venous pressure at the low readings. At the higher level of $\mathrm{CO}_{2}$ concentration, however, a significant rise in GVP accompanied the rise in IOP $(\mathrm{P}<0 \cdot 05)$.

The mean value in the five patients in whom the IOP was measured before induction of anaesthesia was $16.4 \mathrm{~mm}$. Hg (Normal range: $10 \cdot 5-20 \cdot 5$ : Leydhecker, Akiyama, and Neumann, 1958). Under general anaesthesia, the mean IOP in these five patients fell slightly to ${ }_{5} \mathrm{~mm}$. $\mathrm{Hg}$, in the physiological range of $\mathrm{FE}^{\prime} \mathrm{CO}_{2}$, and fell even further to I I $\cdot 2 \mathrm{~mm}$. $\mathrm{Hg}$, at the lower 3 per cent. level of $\mathrm{FE}^{\prime} \mathrm{CO}_{2}$. When the $\mathrm{FE}^{\prime} \mathrm{CO}_{2}$ was 8 per cent. the mean IOP rose above the waking level to $19 \mathrm{~mm}$. $\mathrm{Hg}$.

\section{Discussion}

The ability to control the IOP is beneficial during ophthalmic operations. Hitherto, this has involved the use of pharmacological agents, such as muscle relaxants, mannitol 
servation 3

\begin{tabular}{|c|c|c|c|c|c|c|c|c|c|}
\hline$\because \mathrm{CO}_{2}$ & $I O P$ & $B P$ & $H R$ & $C V P$ & $\mathrm{FE}^{\prime} \mathrm{CO}_{2}$ & $I O P$ & $B P$ & $H R$ & $C V P$ \\
\hline ) & $\begin{array}{l}13 \cdot 0 \\
(13 \cdot 0)\end{array}$ & $\begin{array}{l}120 \\
(9 \cdot I)\end{array}$ & $\begin{array}{l}68 \\
(-5 \cdot 6)\end{array}$ & $\left.5_{(I I} \cdot 1\right)$ & & & & & \\
\hline $\begin{array}{l}j \\
j \cdot 0)\end{array}$ & $\begin{array}{l}\mathbf{1} 5.0 \\
(200 \cdot 0)\end{array}$ & $\begin{array}{l}\text { I I } 5 \\
(-4 \cdot 2)\end{array}$ & ${ }^{65}$ - $\left.10 \cdot 0\right)$ & $\begin{array}{l}-1 \\
(0 \cdot 0)\end{array}$ & $\begin{array}{l}3 \cdot 5 \\
(-30 \cdot 0)\end{array}$ & $\begin{array}{l}4 \cdot 0 \\
(-20 \cdot 0)\end{array}$ & $\begin{array}{l}\text { I } 20 \\
(0 \cdot 0)\end{array}$ & ${ }^{65}(-10 \cdot 0)$ & $\begin{array}{l}-\mathrm{I} \\
(0 \cdot 0)\end{array}$ \\
\hline $\begin{array}{l}j \\
j \cdot 0)\end{array}$ & $\begin{array}{l}18 \cdot 0 \\
(50 \cdot 0)\end{array}$ & $\stackrel{90}{(-18 \cdot 2)}$ & $\begin{array}{l}90 \\
(20 \cdot 0)\end{array}$ & $3^{3}(50 \cdot 0)$ & $\begin{array}{l}3 \cdot 5 \\
(-30 \cdot 0)\end{array}$ & $\begin{array}{l}5 \cdot 0 \\
\left(-5^{8 \cdot 3}\right)\end{array}$ & $\stackrel{90}{(-18 \cdot 2)}$ & $\begin{array}{l}90 \\
(6 \cdot 7)\end{array}$ & $\begin{array}{l}3 \\
(50 \cdot 0)\end{array}$ \\
\hline $5 \cdot 5)$ & $\begin{array}{l}20 \cdot 0 \\
(14 \cdot 3)\end{array}$ & $\begin{array}{l}\text { I } 25 \\
(4 \cdot 2)\end{array}$ & $\begin{array}{l}90 \\
(6 \cdot 3)\end{array}$ & $\begin{array}{l}2 \cdot 5 \\
(25 \cdot 0)\end{array}$ & $\stackrel{3 \cdot 5}{(-36 \cdot 4)}$ & $\begin{array}{l}\text { I I } \cdot 0 \\
(-37 \cdot I)\end{array}$ & $\begin{array}{l}\text { I } 30 \\
(8 \cdot 3)\end{array}$ & $\begin{array}{l}80 \\
(12 \cdot 5)\end{array}$ & $(-50 \cdot 0)$ \\
\hline $7 \cdot 8)$ & $\begin{array}{l}\mathbf{1} 7 \cdot 0 \\
(30 \cdot 8)\end{array}$ & $\begin{array}{l}\text { I } 50 \\
(7 \cdot 1)\end{array}$ & $\begin{array}{l}85 \\
(0 \cdot 0)\end{array}$ & $\begin{array}{l}8 \cdot 5 \\
(70 \cdot 0)\end{array}$ & $\begin{array}{l}3 \cdot 0 \\
(-33 \cdot 3)\end{array}$ & $\begin{array}{l}8 \cdot 0 \\
(-38 \cdot 5)\end{array}$ & $\begin{array}{l}\text { I8o } \\
(28 \cdot 6)\end{array}$ & $\begin{array}{l}90 \\
(0 \cdot 0)\end{array}$ & $\begin{array}{l}5 \cdot 5 \\
(10 \cdot 0)\end{array}$ \\
\hline $3 \cdot 0)$ & $\begin{array}{l}20 \cdot 0 \\
(25 \cdot 0)\end{array}$ & $\begin{array}{l}160 \\
(6 \cdot 8)\end{array}$ & $\begin{array}{l}80 \\
(9 \cdot 1)\end{array}$ & $\begin{array}{l}6 \\
(0 \cdot 0)\end{array}$ & $\begin{array}{l}3 \cdot 0 \\
(-40 \cdot 0)\end{array}$ & $\begin{array}{l}\text { I } 2 \cdot 0 \\
(-25 \cdot 0)\end{array}$ & $\begin{array}{l}\text { I } 50 \\
(0 \cdot 0)\end{array}$ & $\begin{array}{l}80 \\
(-4 \cdot 6)\end{array}$ & $\begin{array}{l}6 \cdot 0 \\
(0 \cdot 0)\end{array}$ \\
\hline $\begin{array}{l}3 \cdot 0) \\
j \cdot 0\end{array}$ & $\begin{array}{l}23 \cdot 0 \\
(2 I \cdot I)\end{array}$ & $\begin{array}{l}140 \\
(7 \cdot 7)\end{array}$ & $\begin{array}{l}120 \\
(0 \cdot 0)\end{array}$ & $\begin{array}{l}7 \\
(7 \cdot 7)\end{array}$ & $\begin{array}{l}3 \cdot 0 \\
(-40 \cdot 0)\end{array}$ & $\left(\frac{3 \cdot 0}{-3} \cdot 6\right.$ & $\begin{array}{l}\text { I } 10 \\
(-15 \cdot 4)\end{array}$ & $\begin{array}{l}\text { I05 } \\
(-12 \cdot 5)\end{array}$ & $\begin{array}{l}7 \\
(7 \cdot 7)\end{array}$ \\
\hline $\begin{array}{l}3 \\
J \cdot 0)\end{array}$ & $\begin{array}{l}22 \cdot 0 \\
(15 \cdot 8)\end{array}$ & $\begin{array}{l}140 \\
(0 \cdot 0)\end{array}$ & $\begin{array}{l}80 \\
(6 \cdot 7)\end{array}$ & $\begin{array}{l}4 \\
(0 \cdot 0)\end{array}$ & $\begin{array}{l}3 \cdot 0 \\
(-40 \cdot 0)\end{array}$ & $\begin{array}{l}12 \cdot 0 \\
(-36 \cdot 8)\end{array}$ & $\begin{array}{l}140 \\
(0 \cdot 0)\end{array}$ & $\begin{array}{l}70 \\
(13 \cdot 3)\end{array}$ & $\begin{array}{l}4 \\
(0 \cdot 0)\end{array}$ \\
\hline $\begin{array}{l}5 \cdot 5) \\
5\end{array}$ & $\begin{array}{l}18 \cdot 0 \\
(50 \cdot 0)\end{array}$ & $\begin{array}{l}\mathbf{I} 20 \\
(9 \cdot \mathbf{I})\end{array}$ & $\begin{array}{l}80 \\
(-5 \cdot 9)\end{array}$ & $\begin{array}{l}4 \cdot 5 \\
(12 \cdot 5)\end{array}$ & $\begin{array}{l}3 \cdot 5 \\
(36 \cdot 4)\end{array}$ & $\begin{array}{l}10 \cdot 0 \\
(-16 \cdot 7)\end{array}$ & $\begin{array}{l}\text { I } 30 \\
(18 \cdot 2)\end{array}$ & $\begin{array}{l}85 \\
(0 \cdot 0)\end{array}$ & $\begin{array}{l}4 \\
(0 \cdot 0)\end{array}$ \\
\hline \multirow[t]{4}{*}{$\begin{array}{l}3 \cdot 0) \\
j \cdot 0\end{array}$} & $\begin{array}{l}19 \cdot 0 \\
(26 \cdot 7)\end{array}$ & $\frac{90}{(-10 \cdot 0)}$ & $\begin{array}{l}80 \\
(0 \cdot 0)\end{array}$ & $\begin{array}{l}5 \\
(0 \cdot 0)\end{array}$ & $\begin{array}{l}3 \cdot 5 \\
(-30 \cdot 0)\end{array}$ & $\begin{array}{l}12 \cdot 0 \\
(-20 \cdot 0)\end{array}$ & $\begin{array}{l}100 \\
(0 \cdot 0)\end{array}$ & $\begin{array}{l}85 \\
(0 \cdot 0)\end{array}$ & $\begin{array}{l}5 \\
(0 \cdot 0)\end{array}$ \\
\hline & $44 \cdot 7$ & $3 \cdot 2$ & $2 \cdot I$ & $17 \cdot 6$ & - & $-3^{I} \cdot 6$ & $2 \cdot 4$ & 0.6 & $2 \cdot 0$ \\
\hline & $53 \cdot 3$ & $8 \cdot 3$ & $8 \cdot 3$ & $22 \cdot 9$ & - & $12 \cdot 4$ & I 3.9 & $8 \cdot 5$ & $23 \cdot 9$ \\
\hline & $<0.05$ & $\mathrm{NS}$ & NS & $<0.05$ & - & $<0.001$ & $\mathrm{NS}$ & $\mathrm{NS}$ & $\mathrm{NS}$ \\
\hline
\end{tabular}

Observation 4 
(1963) who carried out an investigation in dogs. In the latter study suxamethonium was used which is itself known to raise the IOP (Dillon, Sabawala, Taylor, and Gunter, I 957; Schwartz and De Roetth, I958), and moreover animal work is not necessarily relevant to the situation in man, particularly because of differences in vascular anatomy (Wolff and Last, I96I).

The various factors other than carbon dioxide which are known to influence the IOP under general anaesthesia are summarized in Table II. The study was planned in an attempt to keep unchanged as many of them as possible. Premedication and depolarizing relaxants were avoided. Pancuronium was used because it produces less cardiovascular disturbance than other non-polarizing relaxants (McDowell and Glarke, r969). The minute volume and inflation pressure were fixed to minimize changes in intrathoracic pressure, the inspired oxygen percentage was kept constant to avoid effects of oxygen on the blood vessels of the eye, and the position of the patient was stable so that the orbital venous pressure was not influenced by hydrostatic changes.

Table II Some factors leading to reduced intraocular pressure

Vasoconstriction

Relaxation of ocular muscles

Fall in central venous pressure

Arterial hypotension

Decrease in aqueous formation

Increase in aqueous drainage
Adrenergic drugs : topical adrenaline

Hypocarbia from hyperventilation

General anaesthesia with volatile agents: halothane, trichloroethylene, etc. (Munson and others, ig66)

General anaesthesia with non-depolarizing relaxants: curare, gallamine, pancuronium (Roche, 1950)

Facial and retrobulbar nerve block

General anaesthesia avoiding coughing, straining, and vomiting

Fall in orbital venous pressure in head-up position

Induced : halothane, ganglion blockade

Spontaneous: general anaesthesia

Inhibition of active transport mechanism: acetazolamide, cardiac glycosides (Simon, Bonting, and Hawkins, 1962)

Spontaneous and induced hypothermia

Cholinergic drugs: eserine, pilocarpine

Plasma hypertonicity: mannitol, urea, sucrose, glycerol

Digital orbital pressure (Kirsch and Steinman, 1955)

All patients showed a marked fall in IOP when their end-tidal carbon dioxide percentage was reduced to 3 per cent. This reduction was statistically highly significant and in four of the patients the IOP was below the normal range $\left(10 \cdot 5^{-20} \cdot 6 \mathrm{~mm}\right.$. Hg) (Leydhecker and others, I958). Such an acute change is probably not harmful to the normal eye, and indeed during surgery on the open eye the pressure is atmospheric. The effect of carbon dioxide on the IOP in the abnormal eye may be different and a further study is in progress.

The fall in IOP which was observed with reduction of end-tidal carbon dioxide concentration may be the result of vasoconstriction in the choroidal vessels, or of a decrease in aqueous formation, or a combination of both. Aqueous formation is controlled by the enzyme carbonic anhydrase which may be influenced by alterations in the circulating level of $\mathrm{CO}_{2}$.

The rise in IOP which was observed resulted from a reversal of these effects. The significant change in GVP seen during this period of hypercarbia also causes a further increase in the IOP by decreasing aqueous drainage. These findings have implications in the selection of general anaesthetic technique. 


\section{Summary}

The intraocular pressure in relation to different end-tidal carbon dioxide concentrations was investigated in ten patients under general anaesthesia utilizing a muscle relaxant (pancuronium bromide) and controlled ventilation with nitrous oxide and oxygen. In all patients the intraocular pressure was observed to rise as the carbon dioxide concentration was increased and then return to the initial level when the addition of carbon dioxide ceased.

We thank Mr. R. T. Turner-Warwick for permission to study his patients and the theatre staff of St. Peter's Hospital for their co-operation. We are grateful to Mrs. J. Eccles for technical assistance and Mr. I. Perry for computer analysis of the data. We are indebted to Organon Laboratories Ltd. for the gift of a Perkins hand-held tonometer.

\section{References}

ADAms, A. к., and BARnett, к. C. (1966) Anaesthesia, 21, 202

breinin, G. m., and Görtz, H. (i954) A.M.A. Arch. Ophthal., 52, 333

CASEy, T. A., and TrEVOR-ROPER, P. D. (1963) Brit. med. 7., 2, $85 \mathrm{I}$

Collier, c. R., AfFeldt, J. E., and farr, A. F. (i955) 7. Lab. clin. Med., 45, 526

Davis, m. D., DUehr, P. A., and Javid, m. (ig6r) Arch. Ophthal. (Chicago), 65, 526

dillon, J. B., sabawala, P., taylor, D. B., and gunter, R. (1957) Anesthesiology, 18, 439

DUNCALF, D., and RHODEs, D. H. (I963) "Anaesthesia in Clinical Ophthalmology", ist ed., p. 49.

Williams and Wilkins, Baltimore

- and weitzner, s. w. ( 1963) Anesth. et Analg., 42, 232

Kirsch, R. E., and steinman, w. (i955) A.M.A. Arch. Ophthal., 54, 697

Kornblueth, W., Aladjemoff, l., MAgOra, F., and gabbay, A. (i959) Ibid., 6r, 84

leydhegker, w., Akiyama, K., and neumann, H. G. (1958) Klin. Mbl. Augenheilk., 133, 662

mCDOWEll, s. A., and Clarke, R. S. J. (I969) Anaesthesia, 24, 58 I

MUNSON, E. S., LARSON, C. P., BABAD, A. A., REGAN, M. J., BUEGhel, D. R., and Eger, E. I. (I966)

Anesthesiology, 27, 7 I 6

PERKins, E. S. (I965) Brit. 7. Ophthal., 49, 59 I

pierson, R. h., fletcher, A. N., and Gantz, E. St. c. (i956) Analyt. Chem. (Wash.), 28, 12 I 8

roche, J. R. ( 1950) Amer. 7. Ophthal., 33, 9 I

SAmuel, J. R., Grange, R. A., and hawkins, t. D. (1968) Anaesthesia, 23, 543

schwartz, h., and De roetth, A. (I958) Anesthesiology, r9, i I 2

Simon, к. A., bonting, s. L., and hawkins, n. m. (1962) Exp. Eye Res., I, 253

Weiss, D. I., Shaffer, R. N., and wise, B. L. (i962) Arch. Ophthal. (Chicago), 68, 341

WOLfF, E., and LAST, R. J. (196r) "Eugene Wolff's Anatomy of the Eye and Orbit", 5th ed., rev.

R. J. Last, p. 472. Lewis, London 